\title{
Cytotaxonomy of Simulium cauchense Floch \& Abonnenc and Simulium quadrifidum Lutz (Diptera: Simuliidae) in Brazilian Amazonia
}

\author{
Miriam Adriana Alvan-Aguilar/ ${ }^{++}$, Neusa Hamada/ ${ }^{+}$, Peter H Adler*, \\ Sérgio Luiz Bessa Luz**
}

\begin{abstract}
Divisão de Curso em Entomologia, Coordenação de Pesquisas em Entomologia, Instituto Nacional de Pesquisas da Amazônia, Caixa Postal 478, 69011-970 Manaus, AM, Brasil *Division of Entomology, Clemson University, Clemson, South Carolina, US **Centro de Pesquisa Leônidas e Maria Deane-Fiocruz, Manaus, AM, Brasil
\end{abstract}

Simulium cauchense Floch \& Abonnenc and Simulium quadrifidum Lutz are widely distributed in the Amazon region and are morphologically similar at the larval and pupal stages. Chromosomally, these species are readily distinguished by the position of the nucleolar organizer, which is in the short arm of chromosome I in $\mathrm{S}$. cauchense and in the long arm of chromosomes III in S. quadrifidum. They also differ by three fixed inversions. Sex chromosomes are undifferentiated in both species. Chromosomal resolution of the two species allowed us to evaluate four structural features previously used as diagnostic aids at the larval stage. Characters that distinguish larvae of the two species are the number of branches and branching patterns of the dorsal abdominal setae and the dark band on each primary fan. Branching patterns of the gill histoblasts were often diagnostic, with S. quadrifidum exhibiting more proximal branching and $\mathrm{S}$. cauchense more distal branching. Sites where both species occurred sometimes had larvae with one petiole branching proximally and the other distally; in these cases examination of the chromosomes permitted assignment of the specimen to species. Pigmentation patterns of larvae, on the other hand, are highly variable. Color typically is sex linked in both species.

Key words: Simulium (Psaroniocompsa) - polytene chromosomes - cytotaxonomy - Brazilian Amazon

Cytotaxonomic studies of black flies have repeatedly demonstrated the value of chromosomal characters in elucidating phylogenetic relationships, revealing sibling species and providing diagnostic aids for species identification (Rothfels 1988, Adler et al. 2004). In Brazil, numerous black flies have been investigated cytotaxonomically (e.g., Campos et al. 1996, 2001, Charalambous et al. 1996, Hamada \& Adler 1999, Luz 1999, Ríos-Velásquez et al. 2002, Pereira 2004). While chromosomal studies are often essential in revealing sibling species and resolving relationships, the strongest taxonomic and phylogenetic resolution of black flies comes from a combined chromosomal-morphological approach. This approach has permitted an analysis of species diversity in the Amazon Basin (Hamada et al. 2002) that is more critical than has been possible using the conventional morphotaxonomic approach alone.

Various subgeneric classifications have been used for Neotropical black flies. Crosskey and Howard (1997) and Crosskey (2002), for example, recognize the Neotropical subgenus Psaroniocompsa, with 38 species and 5 species groups. Py-Daniel (1983) and Coscarón (1987) consider the S. amazonicum and S. quadrifidum species groups of Crosskey and Howard (1997) to represent their

Partial financial support: Third World Academy of Sciences, PPI 1-3630, 1-3570 (MCT/INPA), CNPq/MCT, Fiocruz

${ }^{+}$Corresponding author. E-mail: nhamada@inpa.gov.br.

${ }^{++} \mathrm{CNPq}$ fellowship

Received 25 November 2004

Accepted 15 April 2005 subgenera Cerqueirellum and Coscaroniellum, respectively. Py-Daniel and Sampaio (1995) ranked these two subgenera as genera. Cytogenetic techniques can provide independent assessments of these phylogenetic hypotheses and yield insight into classification issues.

The objective of the present study is to resolve the chromosomal differences between Simulium cauchense Floch \& Abonnenc and Simulium quadrifidum Lutz, two members of the subgenus Psaroniocompsa (Crosskey \& Howard 1997), and to evaluate the usefulness of morphological discriminators previously used for the larvae. $S$. cauchense is known from Brazil, French Guiana, Guyana, and Venezuela, whereas $S$. quadrifidum, with a slightly broader distribution, is known from Bolivia, Brazil, Colombia, Ecuador, French Guiana, Guyana, Suriname, and Venezuela.

\section{MATERIALSAND METHODS}

Larvae were collected from 15 streams in the states of Amapá, Amazonas, Rondônia, and Roraima (Fig. 1). S. quadrifidum was collected at 13 sites and S. cauchense at 6; the latter species was not collected in the state of Rondônia. Most collections were made in 2000 and 2001, although two collections were made in 1997 and one each was made in 1996, 1999, 2002, and 2003 (Table I).

Larvae were hand collected from all available substrates and fixed in Carnoy's solution (1 part glacial acetic acid: 3 parts absolute ethanol); the fixative was changed 3 or 4 times in the field and the samples were maintained on ice. In the laboratory, the fixative was changed once more and the samples were held at $4{ }^{\circ} \mathrm{C}$, pending chromosomal analysis. 


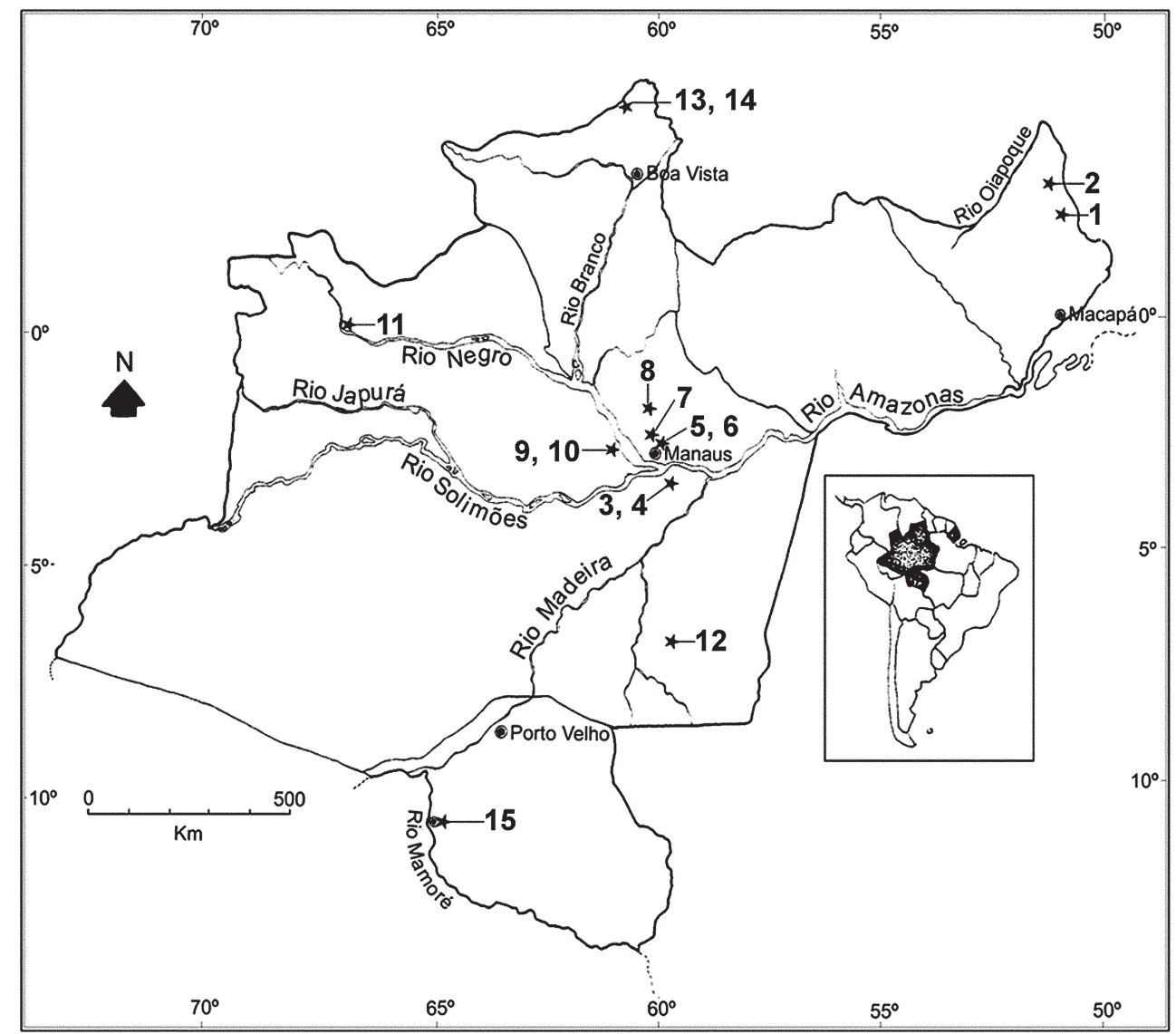

Fig. 1: map of the Brazilian Amazon region, showing collection sites of Simulium quadrifidum and Simulium cauchense (Diptera: Simuliidae).

The following morphological characters of final-instar larvae were evaluated for their utility in species identification: presence of dark spots on the cephalic rays (PyDaniel 1983), branching pattern of the dorsal abdominal setae (Hamada et al. 2003), body pigmentation pattern, and branching pattern of the gill histoblast (Shelley et al. 1997, Hamada \& Grillet 2001, Hamada et al. 2003).

The Feulgen technique (Rothfels \& Dunbar 1953) was used to stain the polytene chromosomes in the silk glands of last-instar larvae. This technique also stained the larval gonads, allowing gender identification in situ based on gonad shape (elongate in females, oval to round in males). The sex chromosomes then can be identified $a$ posteriori by association of rearrangements with gender. Chromosomal nomenclature follows that of Rothfels (1988) and Rothfels et al. (1978). Fixed inversions are italicized in the text and underlined on the figures; floating inversions appear in Roman type.

The banding sequence of $S$. quadrifidum was used as the standard sequence against which the chromosomes of $S$. cauchense were compared, primarily because $S$. quadrifidum had better chromosomal quality. The chromosomes of a male larva from Amazonas (site 5, Table I) were photographed under oil immersion, and maps were constructed for intraspecific and interspecific comparisons.
Larval specimens are deposited in the Clemson University Arthropod Collection (Clemson, South Carolina, US) and the Invertebrate Collection of the Instituto Nacional de Pesquisas da Amazônia (Inpa) (Manaus, AM, Brazil). Photographic negatives of chromosomes are in the Clemson University Arthropod Collection.

\section{RESULTS}

Larval morphology - The most consistent structural features for distinguishing larvae of the two species were the dark spots on the primary rays of the cephalic fan, which typically appeared as a dark band on the fans in $S$. quadrifidum but were absent in S. cauchense (Fig. 2), the number of branches of the dorsal abdominal setae $[S$. quadrifidum, mean $=4.6$ branches $(\mathrm{n}=6, \mathrm{SD}=0.5), S$. cauchense, mean $=6.7$ branches $(\mathrm{n}=9, \mathrm{SD}=1)]$ and branching pattern of the dorsal abdominal setae, with branching starting near the base in S. quadrifidum, whereas in $S$. cauchense the branching occurs both at the base and at points some distance from the base (Fig. 3). The branching patterns of the gill histoblasts (Figs 6, 7) were often diagnostic, with S. quadrifidum exhibiting more proximal branching and $S$. cauchense more distal branching. Sites where both species occurred sometimes had larvae with one petiole branching proximally and the other distally; in these cases the chromosomes permitted as- 
signment of the specimen to species. The pigmentation patterns of the body (Figs 4, 5) were highly variable, but color typically was linked to sex in both species, with males being pale brownish or grayish and females dark gray to black, particularly on abdominal segment I.

Polytene chromosomes - The chromosomes of 630 larvae were examined; $162(25.7 \%)$ could be analyzed completely (i.e., all bands were compared with the standard reference map). For $S$. quadrifidum $(\mathrm{n}=265), 80$ speci- mens (30 females, 50 males) were analyzed completely, whereas for $S$. cauchense $(\mathrm{n}=365), 82$ specimens $(43 \mathrm{fe}-$ males, 39 males) were analyzed completely (Table II). The low numbers of completely analyzed specimens reflected the poor chromosomal quality, in part because most larvae selected for analysis had mature (dark) gill histoblasts to permit association of gill morphology with chromosomes.

Both species had a chromosomal complement of $n=3$,

TABLE I

Sampling sites, dates, and collectors for larvae of Simulium quadrifidum and Simulium cauchense (Diptera: Simuliidae) in Brazilian Amazonia

\begin{tabular}{|c|c|c|c|c|c|}
\hline $\mathrm{Nr}$ & Sampling sites & Coordinates & Date & Collector & Species \\
\hline 1 & $\begin{array}{l}\text { Amapá } \\
\text { Highway BR156, Igarapé Água Branca, } \\
\text { near Carnot Village }\end{array}$ & $02^{\circ} 40^{\prime} \mathrm{S} / 51^{\circ} 21^{\prime} \mathrm{W}$ & $25 / 07 / 00$ & $\mathrm{NH}$ & 1,2 \\
\hline 2 & $\begin{array}{l}\text { Highway BR156, } 90 \mathrm{~km} \text { south of Oiapoque } \\
\text { Amazonas } \\
\text { Careiro da Várzea }\end{array}$ & $03^{\circ} 11^{\prime} \mathrm{S} / 51^{\circ} 32^{\prime} \mathrm{W}$ & $27 / 07 / 00$ & $\mathrm{NH}$ & 1,2 \\
\hline $\begin{array}{l}3 \\
4\end{array}$ & $\begin{array}{l}\text { Road to Purupurú, dirt road Cobra, first bridge } \\
\text { Road to Purupurú, dirt road Cobra, second bridge }\end{array}$ & $\begin{array}{l}03^{\circ} 23^{\prime} \mathrm{S} / 59^{\circ} 38^{\prime} \mathrm{W} \\
03^{\circ} 23^{\prime} \mathrm{S} / 59^{\circ} 38^{\prime} \mathrm{W}\end{array}$ & $\begin{array}{l}10 / 06 / 01 \\
10 / 06 / 01\end{array}$ & $\begin{array}{l}\text { MA; JS; LA } \\
\text { MA; JS; LA }\end{array}$ & $\begin{array}{l}1 \\
1\end{array}$ \\
\hline 5 & $\begin{array}{l}\text { Manaus } \\
\text { Road to Riacho Ecológico, entrance of Trigolar } \\
\text { Chácara São Sebastião }\end{array}$ & $02^{\circ} 58^{\prime} \mathrm{S} / 60^{\circ} 03^{\prime} \mathrm{W}$ & $02 / 05 / 96$ & $\mathrm{NH}$ & 1 \\
\hline 6 & $\begin{array}{l}\text { Highway AM010 km 30, dirt road Água Branca II, } \\
\text { Igarapé Matrinxã, Green Park }\end{array}$ & $02^{\circ} 51^{\prime} \mathrm{S} / 59^{\circ} 51^{\prime} \mathrm{W}$ & $\begin{array}{l}05 / 10 / 00 \\
12 / 05 / 01\end{array}$ & $\begin{array}{l}\text { MA; JS; SL } \\
\text { MA; JS }\end{array}$ & $\begin{array}{l}1,2 \\
1,2\end{array}$ \\
\hline 7 & Highway BR174 km 40, Igarapé Cabeça Branca & $02^{\circ} 35^{\prime} \mathrm{S} / 60^{\circ} 01^{\prime \prime} \mathrm{W}$ & $\begin{array}{l}16 / 08 / 00 \\
17 / 10 / 01\end{array}$ & $\begin{array}{l}\text { MA; JS } \\
\text { JS; SC }\end{array}$ & $\begin{array}{l}1 \\
1\end{array}$ \\
\hline 8 & $\begin{array}{l}\text { Presidente Figueiredo } \\
\text { Highway BR174 km 134, dirt road to comunidade } \\
\text { do Castanhal, Igarapé Canoas }\end{array}$ & $01^{\circ} 49^{\prime} \mathrm{S} / 60^{\circ} 04^{\prime} \mathrm{W}$ & $\begin{array}{l}16 / 12 / 97 \\
03 / 01 / 01 \\
17 / 10 / 01 \\
05 / 11 / 01 \\
12 / 11 / 02 \\
08 / 10 / 03\end{array}$ & $\begin{array}{l}\text { NH } \\
\text { MA; JS } \\
\text { MA; JS } \\
\text { AP } \\
\text { JS } \\
\text { NH }\end{array}$ & $\begin{array}{l}2 \\
2 \\
2 \\
2 \\
2 \\
2\end{array}$ \\
\hline $\begin{array}{l}9 \\
10\end{array}$ & $\begin{array}{l}\text { Novo Airão } \\
\text { Highway AM352, Manacapuru, Novo Airão } \\
\text { Highway AM352, Manacapuru, Novo Airão }\end{array}$ & $\begin{array}{l}02^{\circ} 58^{\prime} \mathrm{S} / 60^{\circ} 56^{\prime} \mathrm{W} \\
02^{\circ} 48^{\prime} \mathrm{S} / 60^{\circ} 55^{\prime} \mathrm{W}\end{array}$ & $\begin{array}{l}18 / 06 / 01 \\
19 / 06 / 01\end{array}$ & $\begin{array}{l}\text { MA; JS; LA } \\
\text { MA; JS; LA }\end{array}$ & $\begin{array}{l}1 \\
1\end{array}$ \\
\hline 11 & $\begin{array}{l}\text { São Gabriel da Cachoeira } \\
\text { Igarapé Miuá }\end{array}$ & $00^{\circ} 06^{\prime} \mathrm{S} / 66^{\circ} 52^{\prime} \mathrm{W}$ & $\begin{array}{l}04 / 12 / 00 \\
07 / 12 / 00\end{array}$ & $\begin{array}{l}\text { NH; EP } \\
\text { NH; EP }\end{array}$ & $\begin{array}{l}1 \\
1\end{array}$ \\
\hline 12 & $\begin{array}{l}\text { Apuí } \\
\text { Rio Juma, Balneário Apuí }\end{array}$ & $07^{\circ} 12^{\prime} \mathrm{S} / 59^{\circ} 54^{\prime} \mathrm{W}$ & 03/05/99 & NH & 1 \\
\hline & $\begin{array}{l}\text { Roraima } \\
\text { Pacaraima }\end{array}$ & & & & \\
\hline 13 & $\begin{array}{l}\text { Highway BR174, dirt road to Maloca Bananal, } \\
\text { Igarapé Bananal }\end{array}$ & $04^{\circ} 25^{\prime} \mathrm{S} / 61^{\circ} 13^{\prime} \mathrm{W}$ & $\begin{array}{l}10 / 12 / 97 \\
13 / 12 / 00 \\
20 / 03 / 01 \\
25 / 10 / 01\end{array}$ & $\begin{array}{l}\text { NH } \\
\text { NH; MA } \\
\text { NH; JS } \\
\text { NH }\end{array}$ & $\begin{array}{l}1,2 \\
1,2 \\
1,2 \\
1,2\end{array}$ \\
\hline 14 & $\begin{array}{l}\text { Highway BR174, dirt road to Maloca Bananal, } \\
\text { Igarapé Sorocaima }\end{array}$ & $04^{\circ} 25^{\prime} \mathrm{S} / 61^{\circ} 13^{\prime} \mathrm{W}$ & $\begin{array}{l}13 / 12 / 00 \\
20 / 03 / 01 \\
25 / 10 / 01\end{array}$ & $\begin{array}{l}\text { NH; MA } \\
\text { NH; JS } \\
\text { NH }\end{array}$ & $\begin{array}{l}2 \\
2 \\
2\end{array}$ \\
\hline & $\begin{array}{l}\text { Rondônia } \\
\text { Guajará-Mirim }\end{array}$ & & & & \\
\hline 15 & Dirt road to Palheta, after airport & $10^{\circ} 47^{\prime} \mathrm{S} / 65^{\circ} 12^{\prime} \mathrm{W}$ & $22 / 09 / 01$ & $\mathrm{NH}$ & 1 \\
\hline
\end{tabular}

Nr: number of collection. Dates are given as day/month/year. Federal highway = BR, Amazonas state highway = AM. Date: day/ month/year. Collectors: AP, Ana Maria de Oliveira Pes; EP, Eleny da Silva Pereira; JS, Jeferson Oliveira da Silva; LA, Luis Aquino; MA, Miriam Alvan Aguilar; NH, Neusa Hamada; SC, Sheyla Couceiro; SL, Sérgio Luis Bessa Luz. Species: 1, Simulium quadrifidum; 2, Simulium cauchense 
with standard arm associations (Figs 8-11). The most readily apparent interspecific difference was the position of the nucleolar organizer, which was in the extreme base of IS in S. cauchense and in the base of IIIL in $S$. quadrifidum (Fig. 11). S. quadrifidum had a more ex-
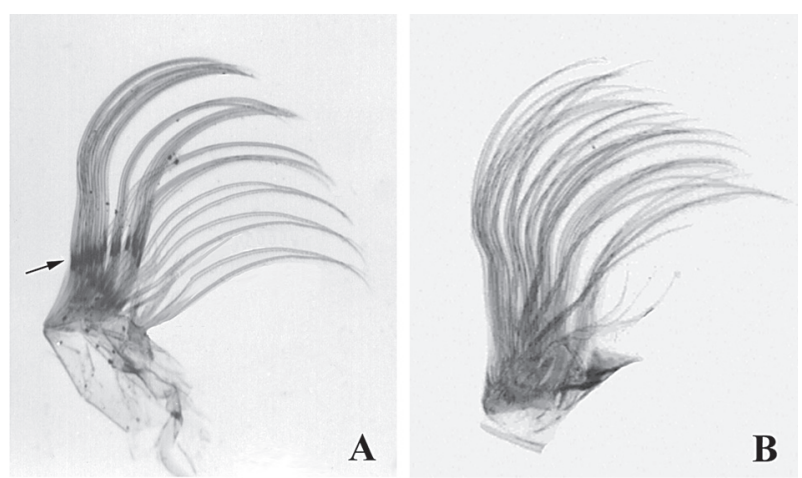

Fig. 2: cephalic fan of larvae of Simulium quadrifidum (A) and Simulium cauchense (B) (Diptera: Simuliidae); arrow indicates dark band on primary fan.
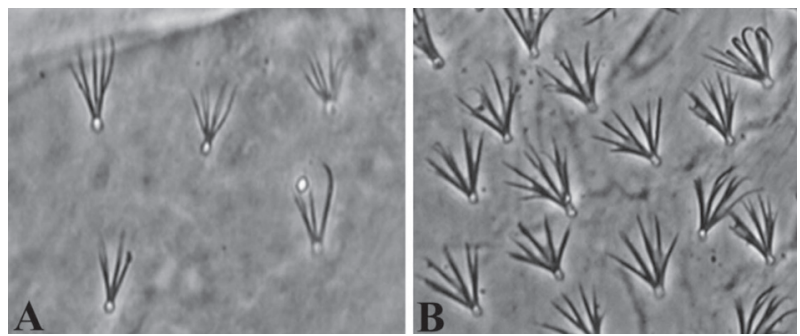

Fig. 3: dorsal abdominal setae of larvae of Simulium quadrifidum (A) and Simulium cauchense (B) (Diptera: Simuliidae). panded centromere region in chromosome I than $\operatorname{did} S$. cauchense (Fig. 8).

S. cauchense also differed from $S$. quadrifidum by three fixed inversions. Inversion IIIS-1 ran from the middle of section 76 to the end of section 80 (Fig. 10). Inversions IIIL-1 and IIIL-2 overlapped broadly (Figs 10,11). The IIIL sequence for $S$. cauchense can be derived from that for $S$. quadrifidum by first inverting the IIIL-1 sequence, followed by the IIIL-2 sequence (Fig. 10). Polymorphisms were not found in S. quadrifidum. Two floating inversions were discovered in S. cauchense. Three larvae from Presidente Figueiredo had a subbasal heterozygous inversion in IL (Fig. 11, IL-1). IIIL-3 (Fig. 10) was a common polymorphism in Hardy-Weinberg equilibrium $\left(\mathrm{G}_{\text {adj. }}=\right.$ $0.1991, p>0.05$ ) for the one population that was tested (Presidente Figueiredo, 8 October 2003). Both species had undifferentiated sex chromosomes. No evidence of sibling species was found.

\section{DISCUSSION}

S. quadrifidum and S. cauchense have consistent structural characters that distinguish them in the adult stage (Py-Daniel 1983, Shelley et al. 1997); however, we found that some larval characters previously considered diagnostic (e.g., body pigmentation) overlap, confounding species identification. The polytene chromosomes allow unequivocal assignment of larvae to species.

The polytene chromosomes of $S$. quadrifidum were of higher quality than those of $S$. cauchense. Inferior chromosomal quality has been attributed to factors such as larval age, water temperature, and the quality and quantity of food (e.g., McCreadie \& Colbo 1992). In the Amazonian region, the temperature of Simuliidae habitats varies little (Hamada \& Adler 2001), suggesting that differ-
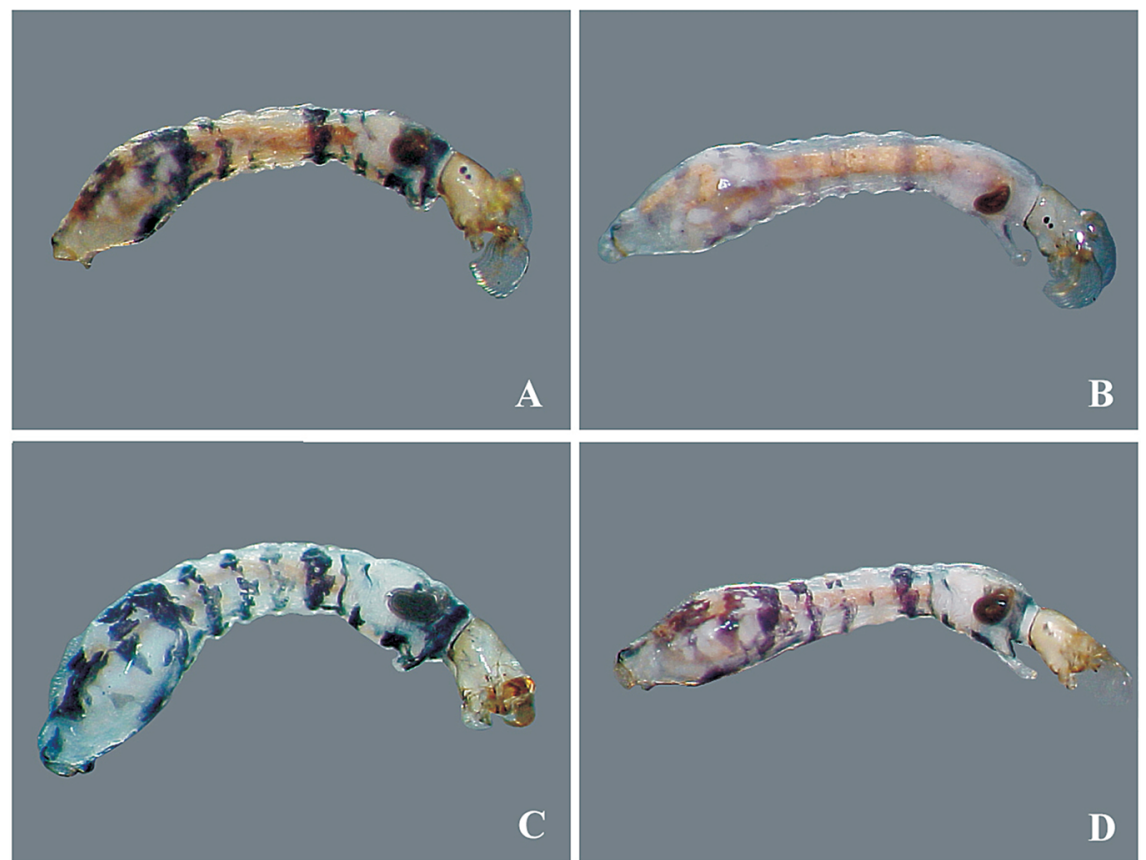

Fig. 4: variation in pigmentation pattern of larvae of Simulium quadrifidum (Diptera: Simuliidae). A: female larva, Igarapé Água Branca, AP (site 1); B: male larva, Igarapé Matrinxã, AM (site 6); C: female larva, Igarapé Bananal, RR (site 13); D: female larva, Ramal Palheta, RO (site 15). 

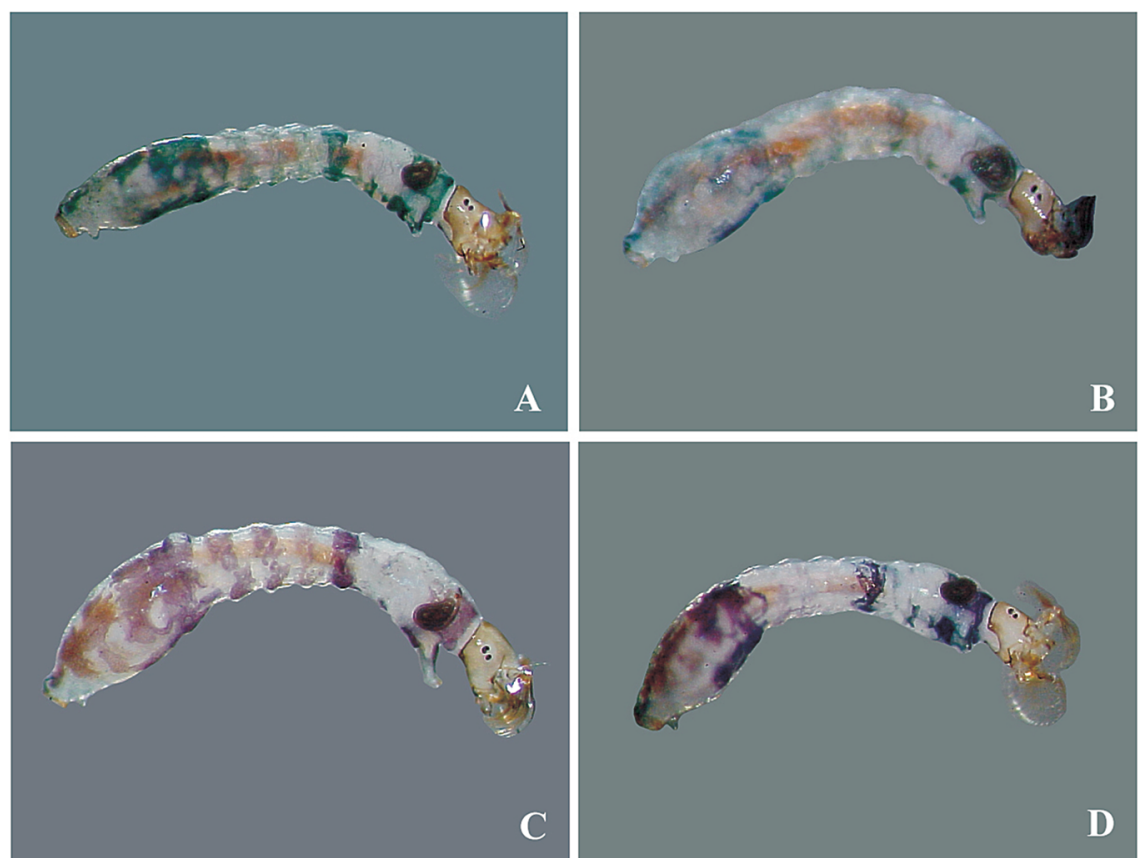

Fig. 5: variation in pigmentation pattern of larva of Simulium cauchense (Diptera: Simuliidae). A: female larva, Igarapé Água Branca, AP (site 1); B: male larva, Igarapé Matrinxã, AM (site 6); C: female larva, Igarapé Canoas, AM (site 8); D: female larva, Igarapé Bananal, RR (site 13).

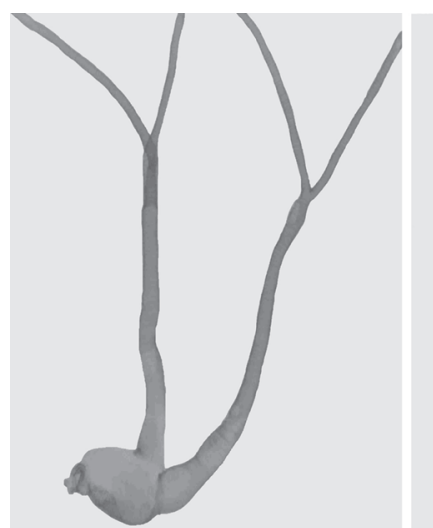

A
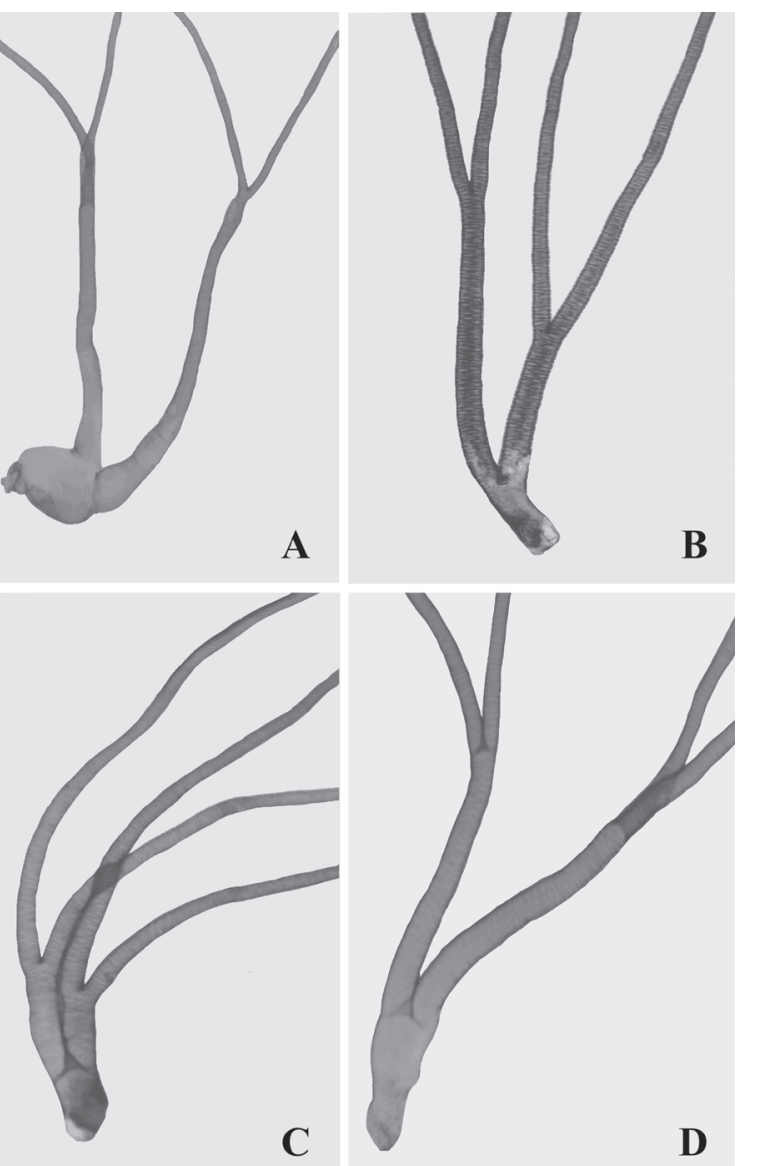

Fig. 6: variation in branching pattern of gill filaments of Simulium quadrifidum (Diptera: Simuliidae). A: Igarapé Água Branca, AP (site 1); B: Igarapé Matrinxã, AM (site 6); C: Novo Airão, AM (site 10); D: Ramal Palheta, RO (site 15).
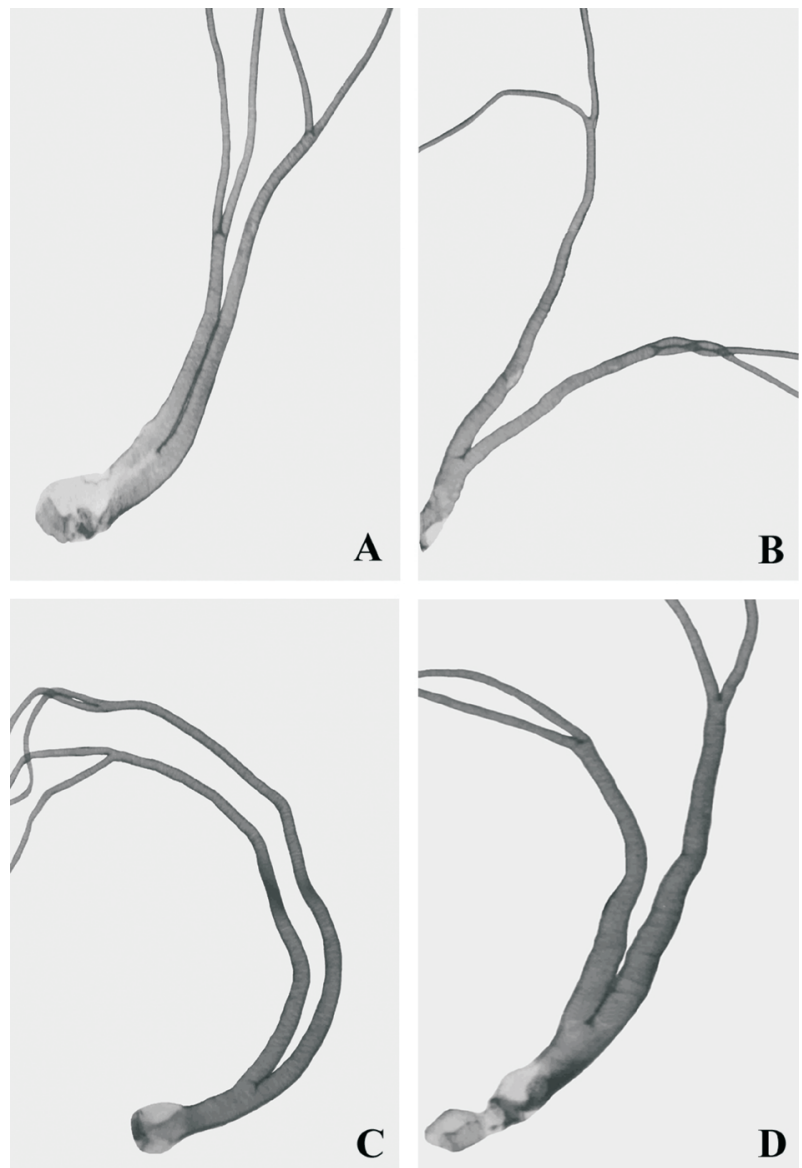

Fig. 7: variation in branching pattern of gill filaments of Simulium cauchense (Diptera: Simuliidae). A: Igarapé Água Branca, AP (site 1); B: Igarapé Matrinxã, AM (site 6); C: Igarapé Canoas, AM (site 8); D: Igarapé Bananal, RR (site 13). 


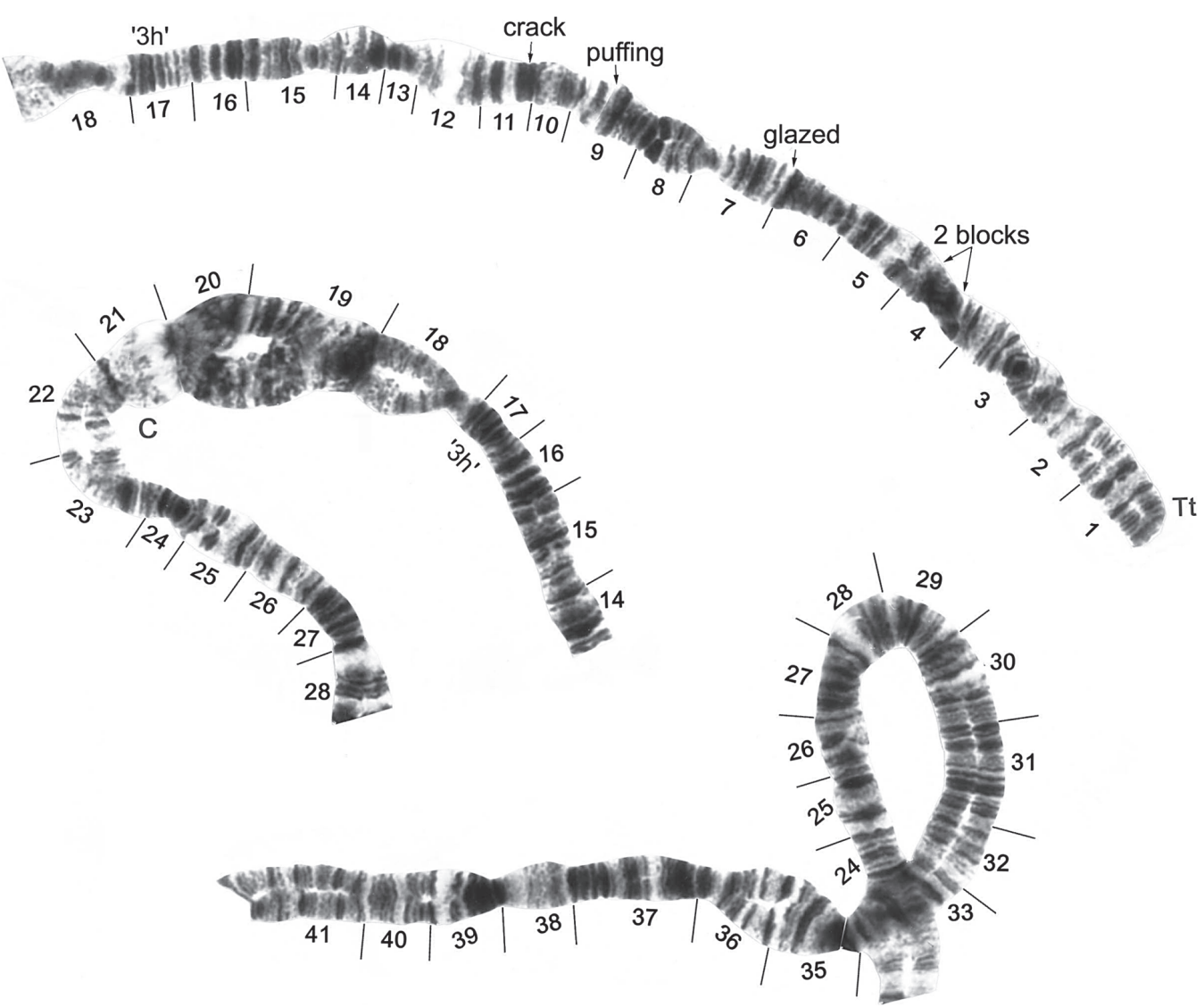

Fig. 8: chromosome I of Simulium quadrifidum (Diptera: Simuliidae), showing standard banding sequence of short arm (top), centromere region (middle), and long arm (bottom); C: centromere, Tt: terminal bands, '3h': three heavy bands.
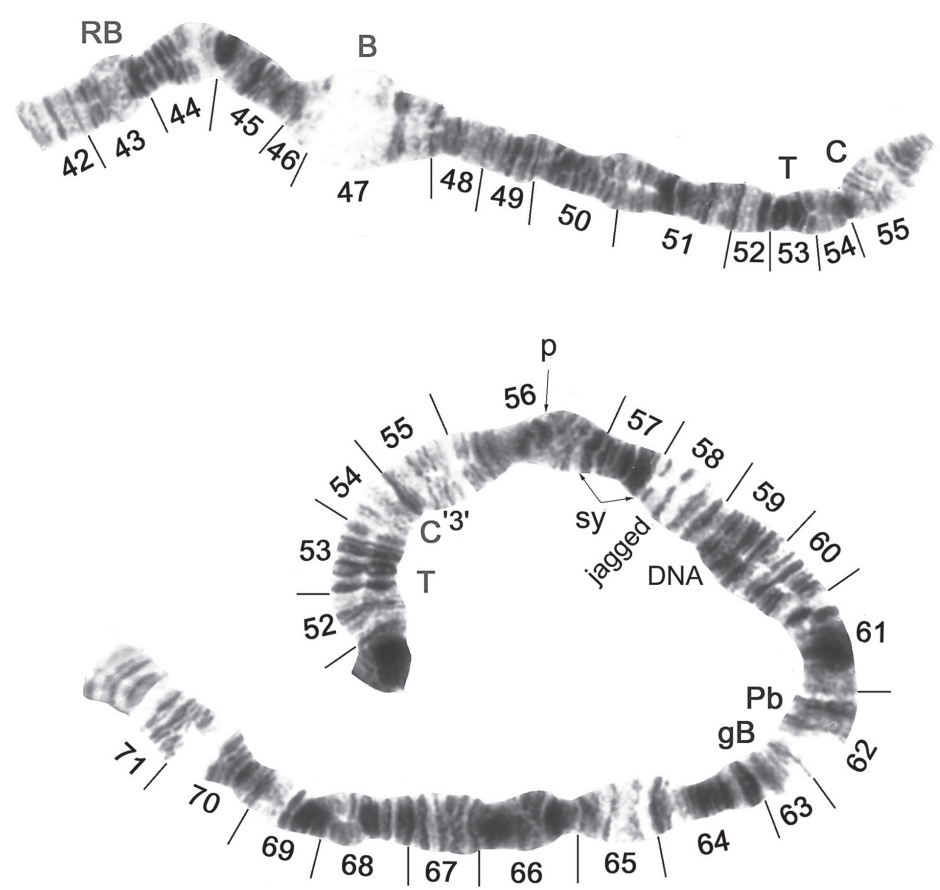

Fig. 9: chromosome II of Simulium quadrifidum (Diptera: Simuliidae), showing standard banding sequence of short arm (top) and long arm (bottom); B: bulge, C: centromere, DNA: DNA puff, gB: gray band, p: puffing band, Pb: parabalbiani, Rb: ring of Balbiani, sy: symmetrical, T: trapezoid, '3': three sharp bands. 
ences in chromosomal quality between species cannot be attributed solely to water temperature. Ríos-Velásquez et al. (2002) suggested that the chromosomal quality of $S$. goeldii Cerqueira \& Nunes de Mello and S. ulyssesi (PyDaniel \& Coscarón 2001) is related to stream size and the degree of habitat shading, which are positively correlated with phytoplankton and periphyton production, the main food sources of black flies in Amazonia (Alencar et al. 2001).

Polymorphisms were not found in S. quadrifidum and were restricted to two floating inversions in S. cauchense. Low levels of inversion polymorphism are characteristic of other black flies in Brazil (e.g., Campos et al. 1996, 2001, Hamada \& Adler 1999, Rios-Velásquez et al. 2002). The chromosomes of black flies in the central and northern areas of South America, however, are typically polymorphic (e.g., Procunier et al. 1985, Conn et al. 1989, Millest 1992, Hirai et al. 1994). The ecological correlates of chromosomal polymorphism in black flies remain poorly understood.

Although the position of the nucleolar organizer is usually conserved among closely related species (Rothfels 1988, Hamada \& Adler 1999), it differs between $S$. quadrifidum and $S$. cauchense. In other members of the
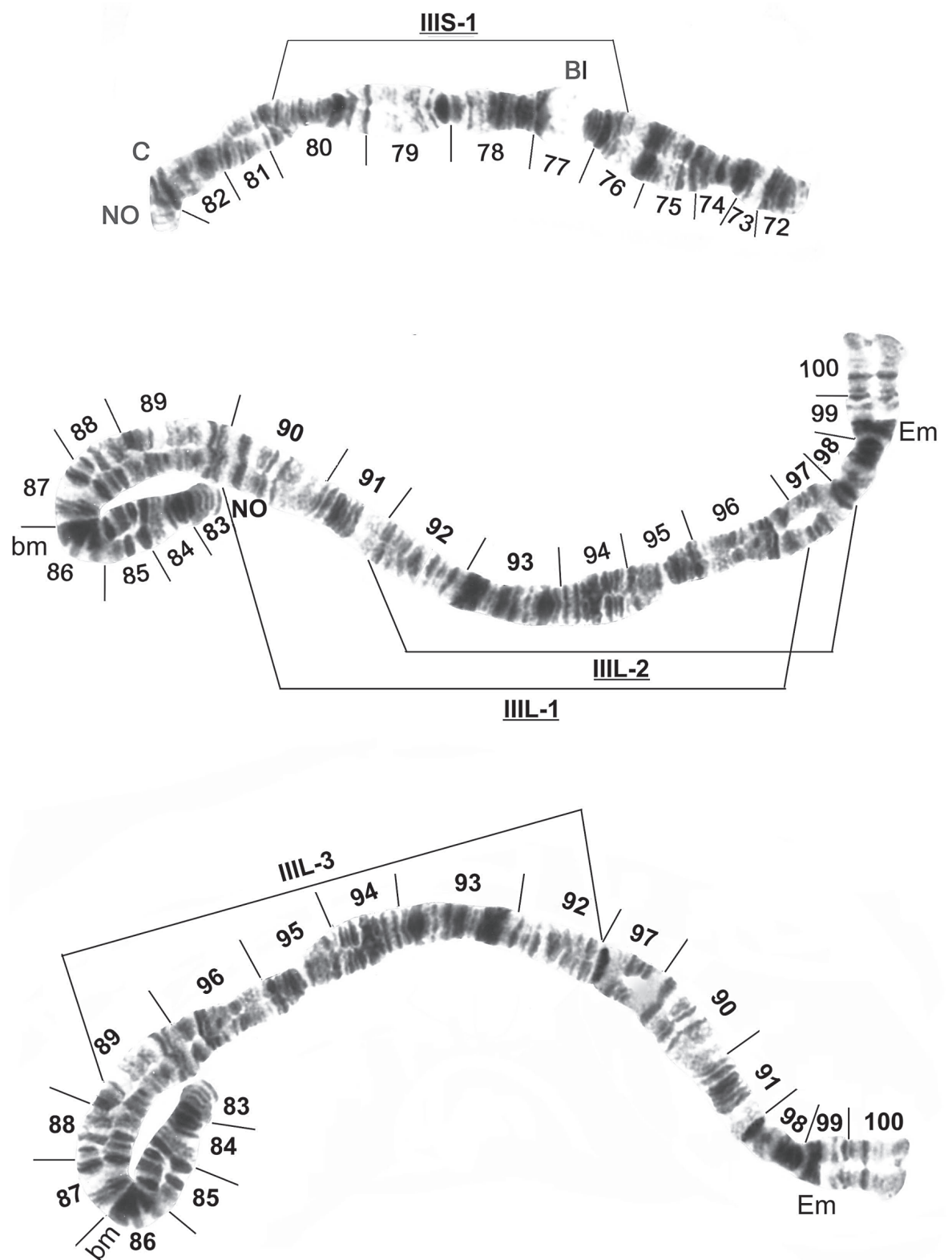

Fig. 10: chromosome III, showing standard banding sequence of short arm (top) and long arm (middle) of Simulium quadrifidum and long arm of Simulium cauchense (bottom) (Diptera: Simuliidae). Limits of inversions IIIS-1, IIIL-1, and IIIL-2 of S. cauchense are indicated by brackets on the standard maps of S. quadrifidum. The map of IIIL for S. cauchense (bottom) was made by cutting and reassembling the standard map of $S$. quadrifidum. The IIIL sequence for $S$. cauchense (bottom) can be derived from the $S$. quadrifidum sequence (middle) by first inverting IIIL-1 and then inverting IIIL-2 on the middle map. The limits of the common floating inversion IIIL-3 in $S$. cauchense are bracketed on the map of $S$. cauchense (bottom). Bl: blister; bm: basal marker; C: centromere; Em: end marker; NO: nucleolar organizer. 


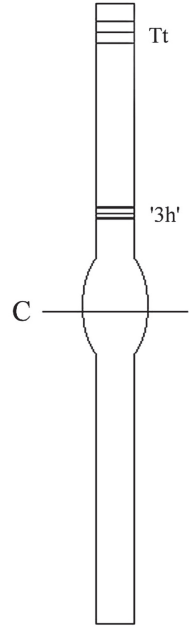

I

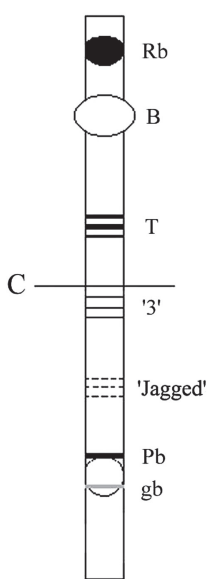

II

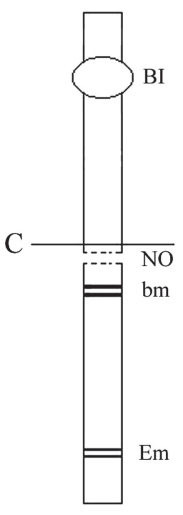

III

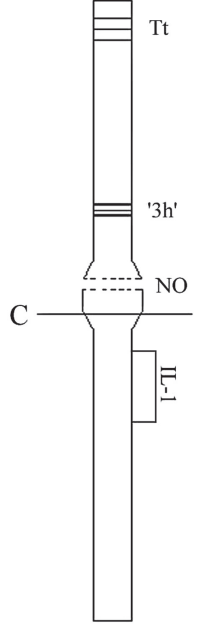

I

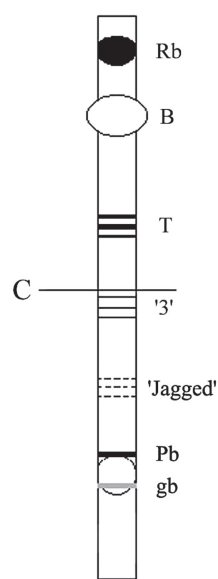

II

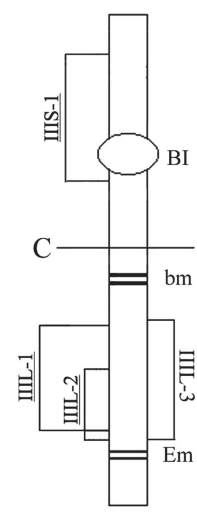

III

Simulium quadrifidum

Simulium cauchense

Fig. 11: idiograms of polytene chromosome of Simulium quadrifidum and Simulium cauchense (Diptera: Simuliidae). I: chromosome I; II: chromosome II; III: chromosome III; C: centromere; B: bulge; Bl: blister; bm: basal marker; Em: end marker; gB: gray band; NO: nucleolar organizer; $\mathrm{Pb}$ : parabalbiani; Rb: ring of Balbiani; T: trapezoid; Tt: terminal bands; ' $3 \mathrm{~h}$ ': three heavy bands; ' 3 ': three sharp bands. Fixed inversions are underlined and shown on the left side; floating inversions are shown on the right side.

\section{TABLE II}

Total number (n) of larvae of Simulium quadrifidum and Simulium cauchense (Diptera: Simuliidae) examined chromosomally, with the number of female and male larvae analyzed completely, in the Brazilian Amazon region

\begin{tabular}{|c|c|c|c|c|c|c|}
\hline \multirow{3}{*}{$\begin{array}{l}\text { State } \\
\text { Site number }\end{array}$} & \multicolumn{6}{|c|}{ Species } \\
\hline & \multicolumn{3}{|c|}{ Simulium quadrifidum } & \multicolumn{3}{|c|}{ Simulium cauchense } \\
\hline & $\mathrm{n}$ & Females & Males & $\mathrm{n}$ & Females & Males \\
\hline \multicolumn{7}{|l|}{ Amapá } \\
\hline 1 & 5 & 1 & 2 & 12 & 0 & 0 \\
\hline 2 & 5 & 0 & 0 & 12 & 2 & 1 \\
\hline \multicolumn{7}{|l|}{ Amazonas } \\
\hline 3 & 8 & 0 & 0 & - & - & - \\
\hline 4 & 5 & 1 & 0 & - & - & - \\
\hline 5 & 1 & 0 & 1 & - & - & - \\
\hline 6 & 53 & 8 & 25 & 10 & 3 & 1 \\
\hline 7 & 78 & 0 & 6 & - & - & - \\
\hline 8 & - & - & - & 178 & 24 & 28 \\
\hline 9 & 3 & 0 & 0 & - & - & - \\
\hline 10 & 1 & 0 & 0 & - & - & - \\
\hline 11 & 19 & 3 & 4 & - & - & - \\
\hline 12 & 13 & 6 & 1 & - & - & - \\
\hline \multicolumn{7}{|l|}{ Roraima } \\
\hline 13 & 26 & 7 & 7 & 129 & 9 & 6 \\
\hline 14 & - & - & - & 24 & 5 & 3 \\
\hline \multicolumn{7}{|l|}{ Rondônia } \\
\hline 15 & 43 & 2 & 1 & - & - & - \\
\hline Total & 265 & 30 & 50 & 365 & 43 & 39 \\
\hline
\end{tabular}

$\mathrm{n}$ : total number of larvae identified using at least one diagnostic chromosomal feature (e.g., position of nucleolar organizer), but not necessarily analyzed completely; -: species not collected. Table I provides specific information on sites and dates. subgenus Psaroniocompsa (sensu Crosskey \& Howard 1997), the nucleolar organizer is located in chromosome I (e.g., S. daltanhani, S. goeldii, and S. ulyssesi) (RíosVelásquez et al. 2002, Pereira 2004) or chromosome III (e.g., S. roraimense and S. oyapockense of the $S$. amazonicum group) (Luz 1999). The position of the nucleolar organizer alone, however, must be used with caution in inferring relationships.

The current study provides a template for comparing the chromosomes of other species in the subgenus Psaroniocompsa sensu Crosskey \& Howard (1997). The evaluation of additional morphospecies could reveal sibling species and test the validity of the current subgenera and species groups.

\section{ACKNOWLEDGEMENTS}

To Jeferson O Silva, Ana MO Pes, Sheyla RM Couceiro, Luis Aquino, Eleny S Pereira, and Roberto S Leite for help in fieldwork, and Philip M Fearnside for reviewing the manuscript.

\section{REFERENCES}

Adler PH, Currie DC, Wood DM 2004. The Black Flies (Simuliidae) of North America, Cornell University Press, Ithaca, NY, 941 pp.

Alencar YB, Veiga Ludwig TA, Soares C, Hamada N 2001. Stomach content analysis of Simulium perflavum Roubaud 1906 (Diptera: Simuliidae) larvae from streams in Central Amazonia, Brazil. Mem Inst Oswaldo Cruz 96: 561-576.

Campos J, Andrade CFS, Recco-Pimentel SM 2001. Chromosomal comparisons among and within populations of Simulium (Chirostilbia) pertinax (Diptera, Simuliidae). Mem Inst Oswaldo Cruz 96: 365-369.

Campos J, Recco-Pimentel SM, Andrade CFS 1996. Polytene 
chromosome analysis of a population of Simulium pertinax (Diptera: Simuliidae). Brazilian J Gen 19: 47-52.

Charalambous M, Shelley A, Herzog MM, Luna Dias APA 1996. Four new cytotypes of the onchocerciasis vector blackfly Simulium guianense in Brazil. Med Vet Entomol 10: 111-120.

Conn J, Rothfels KH, Procunier WS, Hirai H 1989. The Simulium metallicum species complex (Diptera: Simuliidae) in Latin America: a cytological study. Can J Zool 67: 12171245.

Coscarón S 1987. El Genero Simulium Latreille em la Región Neotropical: Análisis de los Grupos Supraespecíficos, Espécies que los Integran y Distribución Geográfica (Simuliidae, Diptera), Museu Paraense Emilio Goeldi, Belém, 112 pp.

Crosskey RW 2002. Second Update to the Taxonomic and Geographical Inventory of World Blackflies (Diptera: Simuliidae), Natural History Museum, London, 14 pp.

Crosskey RW, Howard TM 1997. A New Taxonomic and Geographical Inventory of World Blackflies (Diptera: Simuliidae), Natural History Museum, London, 144 pp.

Hamada N, Adler P 1999. Cytotaxonomy of four species in the Simulium perflavum species group (Diptera: Simuliidae) from Brazilian Amazonia. Syst Entomol 24: 273-278.

Hamada N, Adler P 2001. Bionomia e chave para imaturos e adultos de Simulium (Diptera: Simuliidae) na Amazônia Central, Brasil. Acta Amazonica 31: 109-132.

Hamada N, Grillet ME 2001. Black flies (Diptera: Simuliidae) of the Gran Sabana (Venezuela) and Pacaraima Region (Brazil): distributional data and identification keys for larvae and pupae. Entomotropica 16: 29-49.

Hamada N, Ale-Rocha R, Luz SLB 2003. Description of Simulium damascenoi (Diptera: Simuliidae) male and the blackfly species from the state of Amapá, Brazil. Mem Inst Oswaldo Cruz 98: 353-360.

Hamada N, McCreadie JW, Adler PH 2002. Species richness and spatial distributions of blackflies (Diptera: Simuliidae) in streams of Central Amazonia, Brazil. Freshwater Biol 47: 31-40.

Hirai H, Procunier WS, Ochoa JO, Uemoto K 1994. A cytogenetic analysis of the Simulium ochraceum species complex (Diptera: Simuliidae) in Central America. Genome 37: 3653.

Luz SLB 1999. Sistemática Integrada de Simulium oyapockense (Floch \& Abonnenc, 1946) e Simulium roraimense (Nunes de Mello, 1974), Vetores de Onchocerca volvulus no Foco
Amazônico de Oncocercose Humana do Brasil, $\mathrm{PhD}$ Thesis, Fiocruz, Rio de Janeiro, 109 pp.

McCreadie JW, Colbo MH 1992. Spatial distribution patterns of larval cytotypes of the Simulium venustum/verecundum complex (Diptera: Simuliidae) on the Avalon Peninsula, Newfoundland: factors associated with cytotype abundance and composition. Can J Zool 70: 1389-1396.

Millest M 1992. Identification of members of Simulium ochraceum species complex in the three onchocerciasis foci in Mexico. Med Vet Entomol 6: 23-28.

Pereira ES 2004. Citotaxonomia de Simulium (Psaroniocompsa) daltanhani Hamada \& Adler, 1998 (Diptera: Simuliidae) em um Igarapé da Região Amazônica, Brasil, MSc Thesis. Inpa, Manaus, 49 pp.

Procunier WS, Shelley AJ, Arzube M 1985. Sibling species of Simulium exiguum (Diptera: Simuliidae), the primary vector of onchocerciasis in Ecuador. Rev Ecuator Hyg Med Trop 35: 49-59.

Py-Daniel V 1983. Caracterização de dois novos subgêneros em Simuliidae (Diptera: Culicomorpha) Neotropicais. Amazoniana 8: 159-223.

Py-Daniel V, Coscarón S 2001. Simuliidae (Diptera: Culicomorpha) no Brazil. III. Sobre o Coscaroniellum ulyssesi sp. n. Entomol Vect 8: 51-64.

Py-Daniel V, Sampaio RTM 1995. Gêneros e espécies de Simuliidae (Diptera: Culicomorpha) assinalados para o Brasil até 1995. Entomol Vect 2: 117-121.

Ríos-Velásquez C, Hamada N, Adler PH 2002. Cytotaxonomy of Simulium goeldii Cerqueira \& Nunes de Mello and Simulium ulyssesi (Py-Daniel \& Coscarón) (Diptera: Simuliidae) in Central Amazonia, Brazil. Insect Syst Evol 33: 113-120.

Rothfels KH 1988. Cytological approaches to black fly taxonomy. In KC Kim, RW Merritt (eds), Black Flies: Ecology, Population Management, and Annotated World List, Pennsylvania State University Park, PA, p. 39-52.

Rothfels KH, Dunbar RW 1953. The salivary gland chromosomes of the black fly Simulium vittatum Zett. Can J Zool 31: 226-241.

Rothfels KH, Feraday R, Kaneps A 1978. A cytological description of sibling species of Simulium venustum and Simulium verecundum with standard maps for the subgenus Simulium Davies (Diptera). Can J Zool 56: 1110-1128.

Shelley AJ, Lowry CA, Maia-Herzog M, Luna Dias APA, Moraes MAP 1997. Biosystematic studies on the Simuliidae (Diptera) of the Amazonia onchocerciasis focus. Bull Nat Hist Mus 66: 1-124. 
